\title{
Central bank transparency and exchange rate volatility effects on inflation-output volatility
}

\author{
Stephanos Papadamou $^{*}$ • Moïse Sidiropoulos ${ }^{2,4}$ • Eleftherios Spyromitros ${ }^{3,4}$ \\ ${ }^{1}$ University of Thessaly, Department of Economics, Greece \\ ${ }^{2}$ Aristotle University of Thessaloniki, Department of Economics, Greece \\ ${ }^{3}$ Democritus University of Thrace, Department of Economics, Greece \\ ${ }^{4}$ University of Strasbourg, Bureau d'Economie Théorique et Appliquée (BETA), France
}

Received: 23 July 2016

Revised: 5 September 2016

Accepted: 5 September 2016

\begin{abstract}
While the tendency towards more transparent central banks is irrefutable, the effects of more transparent monetary policies mainly on output volatility are not clear-cut. In this note, we estimate our panel for 36 countries over the period 1998-2005 which is characterized by significant changes in central bank transparency levels, using the Prais-Winsten method with PCSEs and controlling for the exchange rate volatility that positively affects inflation and output. We provide evidence in favor of transparency and exchange rate stability policies since they reduce both output and inflation volatility.
\end{abstract}

Keywords: central bank transparency; macroeconomic volatilities; exchange rate volatility; panel data.

JEL Classification Codes: E52, E58, F31

\section{Introduction}

While in the past the predominant policy strategy was monetary targeting, the adoption of an inflation targeting framework by a growing number of central banks highlights the tendency towards greater central bank transparency. As a matter of fact, for a long time, central banks used to be very secretive, but the last fifteen years numerous central banks have started to embrace openness. In this respect, a comprehensive survey of 94 central banks by Fry et al. (2000) reveals that 74 percent of the central banks consider transparency a vital or very important component of their monetary policy framework. The idea behind this study is that there is a role for central bank transparency in the implementation and efficiency of monetary

\footnotetext{
*E-mail: stpapada@uth.gr.

Citation: Papadamou, S, Sidiropoulos, M. and Spyromitros, E. (2016) Central bank transparency and exchange rate volatility effects on inflation-output volatility, Economics and Business Letters, 5(4), 125-133.
} 
policy. In effect, monetary policy decisions do not come as a surprise for investors. By affecting thus the effectiveness of the transmission process through its impact on inflation expectations which are better anchored, heightened transparency leads to a better stabilization of inflation but the effects on output are less clear-cut. This study evaluates the impact of monetary policy transparency on inflation-output volatility and therefore the impact on macroeconomic stability. Moreover, through the price stability effect, exchange rate volatility can also be an important factor affecting macroeconomic stability through its effect on prices and output.

The effects of central bank transparency on macroeconomic and financial variables are highlighted by the existing literature (see among others, Geraats, 2002; Beetsma and Jensen, 2003; Mishkin, 2004; de Mendonça and Simão Filho, 2007; Liu et al., 2008; Wilhelmsen and Zaghini, 2011; Papadamou, 2013; Papadamou et al., 2014, 2015; Horváth and Vaško, 2016) ${ }^{1}$. Specifically, a number of authors have examined the link between central bank transparency indices and macroeconomic volatility ${ }^{2}$. Demertzis and Hughes Hallett (2007), by employing the Eijffinger-Geraats (2006) index, they examine the relationship between central bank transparency and the level and variability of inflation and the output gap over the period 1990-2001. Their results suggest a negative relationship between inflation variability and central bank transparency, which vanishes however when considering the link between the level of inflation and transparency. Moreover, they find a strong positive relationship between transparency and the variability of output. In other words, they suggest that a more transparent monetary policy may be associated with more output volatility because it prevents the authorities from using policy as actively to offset output fluctuations ${ }^{3}$. In the same spirit, Cecchetti and Krause (2002), using the Fry et al. (2000) index find a weak positive association between output variability and transparency. However, these studies are based on very limited country samples or utilize evidence for a single point in time.

Dincer and Eichengreen (2007), expanding the index of Eijffinger and Geraats (2006), they find that the inflation variability is negatively correlated to central bank transparency. They also suggest a negative but relative weak impact of monetary policy transparency on output variability. By conducting a number of robustness checks, they re-estimated the equations using fixed effects and by doing so, and relying exclusively on the time series variation in the data, they produce weaker evidence of real effects of transparency.

In addition, exchange rate volatility is also an important factor affecting inflation and output growth and dispersion. There are numerous studies that have investigated the negative effect of exchange rate volatility on economic growth (see among others, Aghion et al., 2009; Schnabl, 2009; Arratibel et al. 2011) as well as its impact on inflation (Gosh et al. 1996; Bleaney, 1999; Bleaney and Francisco, 2005; Hutchison et al. 2012). However, less attention has been given to the effects of exchange rate volatility on inflation and output volatility. There is a part of the literature suggesting that exchange rate volatility is not important to macroeconomic volatilities (Flood and Rose, 1995; Obstfeld and Rogoff, 2000; Duarte and Stockman, 2002). Another part of the literature considers that there is a relationship between

\footnotetext{
${ }^{1}$ The issue of central bank transparency has been investigated extensively by the literature. Recent studies on central transparency are mainly focused on the relationship between transparency and independence of the central banks (Spyromitros, 2014), the effect of heightened transparency on stock returns via the interest rate (Papadamou et al., 2016), the effect of monetary policy opacity on macroeconomic efficiency in the presence of fiscal corruption (Dai et al., 2015), and James and Lawler (2015) explores whether public disclosure of the central banks information concerning aggregate shocks can serve as a substitute for active stabilization policy.

${ }^{2}$ For a theoretical explanation of the favorable effects of central bank transparency on output and inflation volatility, see Demertzis and Hughes Hallett (2007) and Carboni and Ellison (2011).

${ }^{3}$ In this context, in a more recent study, Demertzis and Hughes Hallett (2015) highlight the important role of constructive ambiguity when considering the effects on inflation and output. It is suggested that constructive ambiguity lowers inflation on average and output volatility (beyond a certain limit), but at the cost of a deflation bias and higher inflation variability.
} 
exchange rate volatility and output and inflation volatility (Barone-Adesi and Yeung, 1990; Ghosh et al., 1997; Bleaney and Fielding, 2002; Sutherland, 2002; Keating and Valcarcel, 2012).

To sum up, despite the fact that central bank transparency seems to be negatively related to the inflation volatility, there is ambiguity regarding the effects of transparency and exchange rate volatility on output volatility. In this context, the examination of both of these variables in a common model allowing for contemporaneous and serial correlation could provide additional empirical information.

In this note, using panel data on transparency from 36 central banks for the period 1998 $2005^{4}$, and historical volatility measures for GDP growth, nominal effective exchange rate changes and inflation ${ }^{5}$, we examine the link between central bank transparency and inflationoutput volatility allowing for contemporaneous correlation and exchange rate volatility effects, by providing empirical evidence in favor of a negative relationship between transparency and output volatility. The main argument behind this result is that highly transparent central bank, by anchoring inflation expectations, provide a smoothing of both short and long term interest rates changes, leading to a better stabilization of consumption, investment decisions and therefore output. Concerning the effects of transparency on inflation volatility, we confirm previous theoretical studies arguing that central bank transparency negatively affects inflation volatility. Additionally, in order to take into account for any possible correlation within panels, we estimate our model by using the Prais-Winsten method with panel corrected standard errors (PCSEs). Finally, as far as exchange rate volatility is considered, it has a significant positive effect on both output and inflation volatilities without affecting the transparency effects.

\section{Empirical analysis}

Before getting into regression results, as preliminary analysis, the scatter plot figures among the two variables of interest each time can show some of the hidden part in the relation. More specifically, figure 1 shows the relationship between the average historical volatility of inflation and the average level of transparency over the whole period.

Similarly figure 2 presents the average GDP volatility versus average transparency, and figure 3 stock price volatility versus transparency level. The first two graphs confirm what we expected from the theoretical model. Higher level of transparency in the way that monetary policy is conducted coexists with lower level of variability in macro data like inflation and GDP variability.

Figure 1. Average Transparency Index Vs. Average Volatility of Inflation 1998-2005.

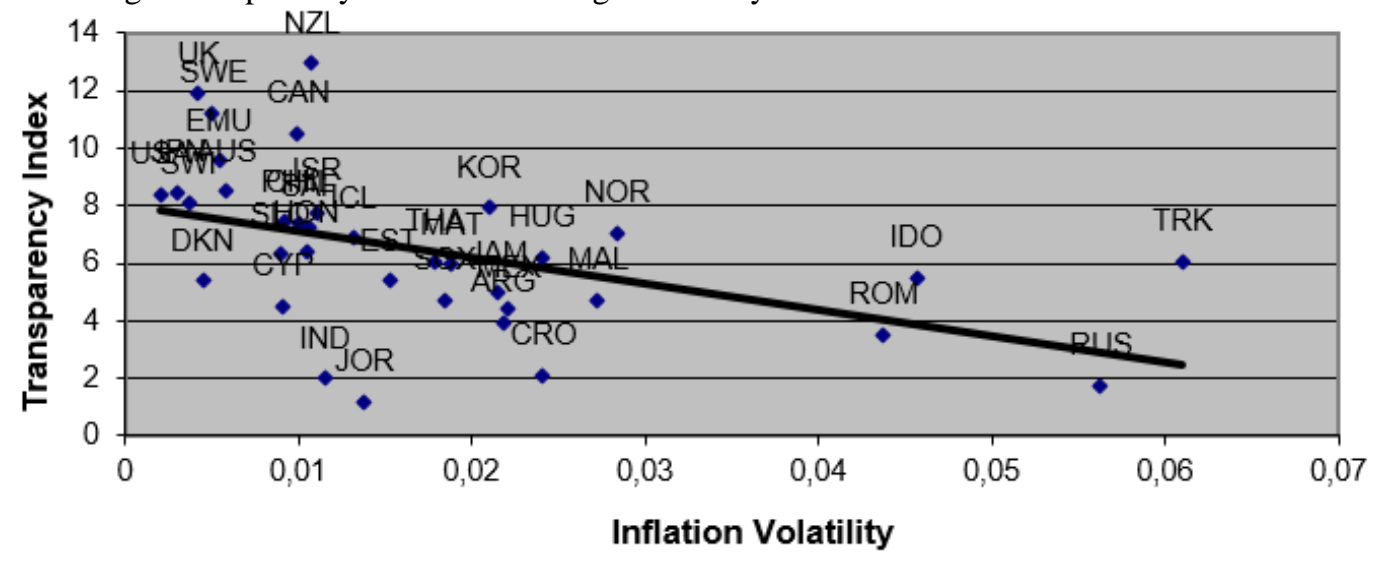

\footnotetext{
${ }^{4}$ It is to notice that major changes in central bank transparency have been contacted over the period 1998-2005.

${ }^{5}$ Gdp growth rates and inflation are taken from International Financial Statistics database of the IMF, while effective exchange rate from the Bank of International Settlements (BIS).
} 
Figure 2. Average Transparency Index Vs. Average Volatility of GDP 1998-2005.

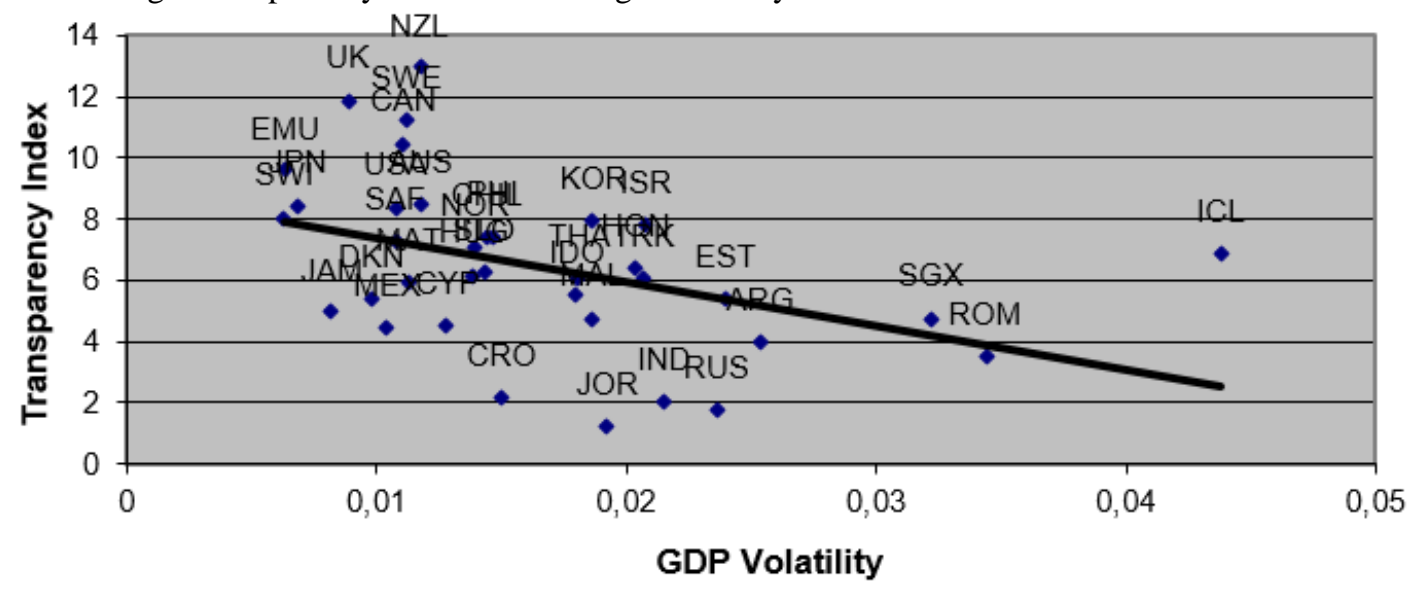

Figure 3. Average Volatility of Effective Exchange Rate Vs Average Volatility of inflation 1998-2005.

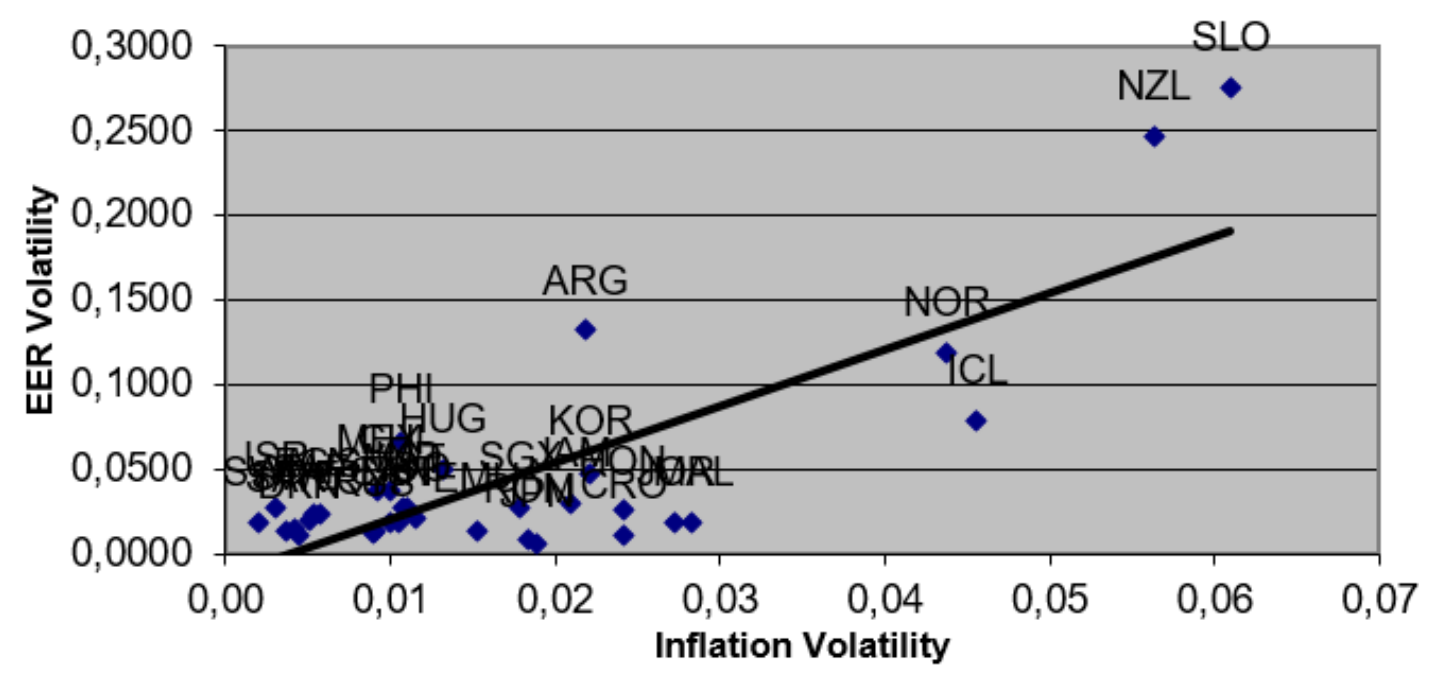

Figure 4. Average Volatility of Effective Exchange Rate Vs. Average Volatility of GDP 1998-2005.

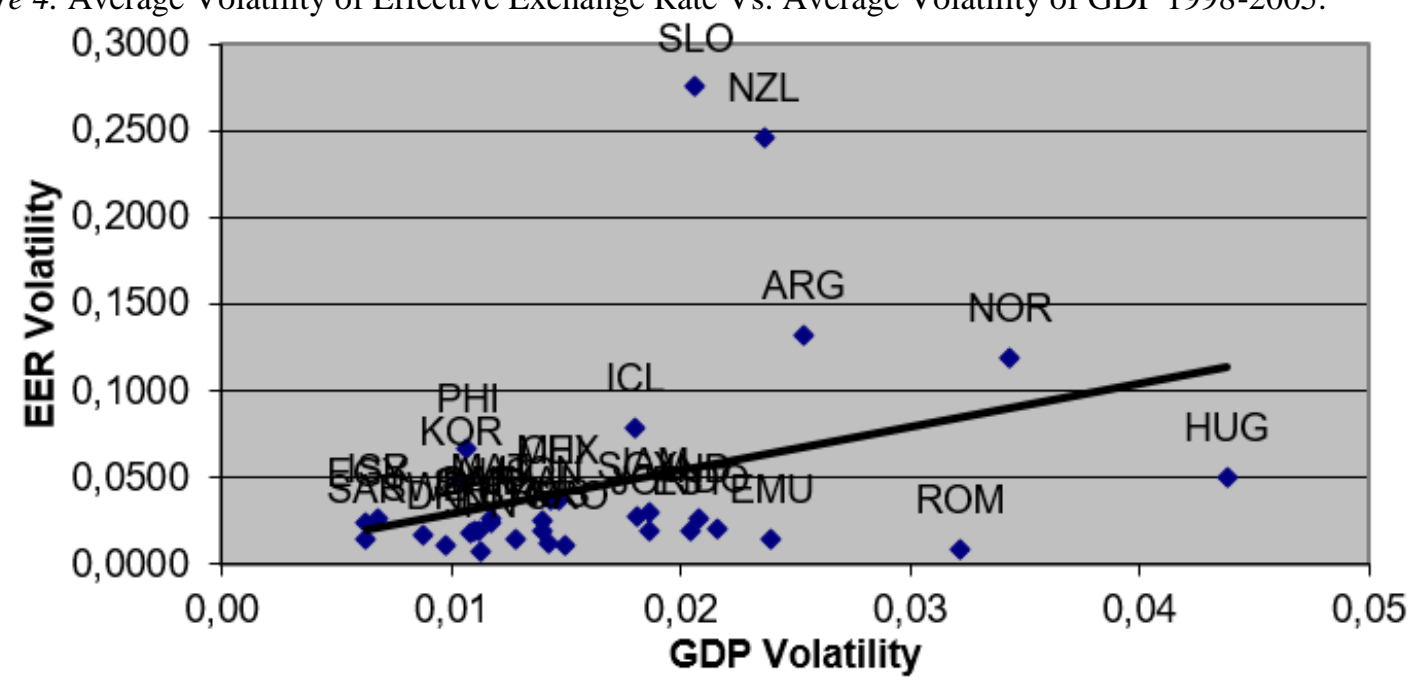

Figures 3 and 4 provide evidence of a positive relation between exchange rate variability and GDP and inflation variability, over the period of the study. Norway New Zealand and Slovenia present among others significant positive correlation between GDP, inflation volatility and effective exchange rate volatility. 
Table 1. Summary Statistics (Averages over the period 1998-2005).

\begin{tabular}{|c|c|c|c|c|c|}
\hline Country & Symbol & $\begin{array}{l}\text { Inflation } \\
\text { Volatility } \\
\end{array}$ & $\begin{array}{c}G D P \\
\text { Volatility } \\
\end{array}$ & $\begin{array}{c}E E R \\
\text { Volatility } \\
\end{array}$ & $\begin{array}{c}\text { Transparency } \\
\text { Index } \\
\end{array}$ \\
\hline Argentina & $\overline{\mathrm{ARG}}$ & 0.0218 & 0.0254 & 0.1317 & 3.9375 \\
\hline Australia & AUS & 0.0058 & 0.0118 & 0.0237 & 8.5000 \\
\hline Canada & $\mathrm{CAN}$ & 0.0100 & 0.0111 & 0.0189 & 10.5000 \\
\hline Chile & CHIL & 0.0101 & 0.0144 & 0.0367 & 7.3750 \\
\hline Croatia & CRO & 0.0241 & 0.0150 & 0.0111 & 2.1250 \\
\hline Cyprus & CYP & 0.0091 & 0.0128 & 0.0134 & 4.5000 \\
\hline Denmark & DKN & 0.0045 & 0.0098 & 0.0112 & 5.3750 \\
\hline Eurozone & EMU & 0.0054 & 0.0063 & 0.0234 & 9.5625 \\
\hline Estonia & EST & 0.0152 & 0.0240 & 0.0143 & 5.3750 \\
\hline Hong Kong & $\mathrm{HON}$ & 0.0104 & 0.0204 & 0.0189 & 6.3750 \\
\hline Hungary & HUG & 0.0241 & 0.0139 & 0.0249 & 6.1875 \\
\hline Iceland & ICL & 0.0132 & 0.0438 & 0.0503 & 6.8750 \\
\hline Indonesia & IDO & 0.0456 & 0.0180 & 0.0785 & 5.5000 \\
\hline India & IND & 0.0115 & 0.0215 & 0.0205 & 2.0000 \\
\hline Israel & ISR & 0.0111 & 0.0208 & 0.0267 & 7.8125 \\
\hline Jamaica & JAM & 0.0215 & 0.0082 & - & 4.9375 \\
\hline Jordan & JOR & 0.0138 & 0.0192 & - & 1.1875 \\
\hline Japan & JPN & 0.0031 & 0.0068 & 0.0267 & 8.4375 \\
\hline Korea & KOR & 0.0210 & 0.0187 & 0.0302 & 7.9375 \\
\hline Malaysia & MAL & 0.0273 & 0.0186 & 0.0187 & 4.7500 \\
\hline Malta & MAT & 0.0189 & 0.0113 & 0.0064 & 5.9375 \\
\hline Mexico & MEX & 0.0221 & 0.0104 & 0.0480 & 4.4375 \\
\hline Norway & NOR & 0.0284 & 0.0139 & 0.0189 & 7.0625 \\
\hline New Zealand & NZL & 0.0108 & 0.0117 & 0.0265 & 12.9375 \\
\hline Philipines & PHI & 0.0093 & 0.0146 & 0.0371 & 7.4375 \\
\hline Romania & ROM & 0.0437 & 0.0344 & 0.1191 & 3.5000 \\
\hline Russia & RUS & 0.0563 & 0.0236 & 0.2465 & 1.7500 \\
\hline S. Africa & SAF & 0.0107 & 0.0107 & 0.0668 & 7.2500 \\
\hline Singapore & SGX & 0.0184 & 0.0322 & 0.0083 & 4.7500 \\
\hline Slovenia & SLO & 0.0090 & 0.0143 & 0.0127 & 6.2500 \\
\hline Sweden & SWE & 0.0051 & 0.0112 & 0.0198 & 11.2500 \\
\hline Switzerland & SWI & 0.0037 & 0.0063 & 0.0141 & 8.0625 \\
\hline Thailand & THA & 0.0179 & 0.0181 & 0.0272 & 6.0625 \\
\hline Turkey & TRK & 0.0610 & 0.0207 & 0.2748 & 6.0625 \\
\hline United Kingdom & UK & 0.0042 & 0.0088 & 0.0158 & 11.8750 \\
\hline United States of America & USA & 0.0021 & 0.0108 & 0.0185 & 8.3750 \\
\hline Avg Across Countries & & 0.0175 & 0.0165 & 0.0453 & 6.4514 \\
\hline
\end{tabular}

Table 1 provides evidence concerning the values of the transparency index, and the different measures of macro variables volatilities, namely the GDP, inflation and exchange rate volatilities. Our sample covers a wide range of countries with various level of central bank transparency.

The panel data estimation results for the effect of transparency on inflation and output volatility based on previous theoretical literature are presented in tables 2 and 3. Two different versions of models are estimated, one that see only the effect of transparency on the dependent variables (column 1), and the other that includes also as a control variable the volatility of the effective exchange rate (column 2). We have to mention at that point that due to data unavailability for the effective exchange rate some countries have been dropped from our data set. 
Table 2. Panel data estimation results for Inflation volatility vs. Transparency.

\begin{tabular}{|c|c|c|c|c|c|c|c|c|c|}
\hline \multirow{2}{*}{$\begin{array}{c}\text { Independent } \\
\text { Variables }\end{array}$} & \multirow{2}{*}{$\begin{array}{c}\text { Expected } \\
\text { Sign }\end{array}$} & \multicolumn{2}{|c|}{ Fixed Effects } & \multicolumn{2}{|c|}{ Random Effects } & \multicolumn{2}{|c|}{ Prais-Winstein } & \multicolumn{2}{|c|}{ Prais-Winstein AR(1) } \\
\hline & & (1) & (2) & (1) & (2) & (1) & (2) & (1) & (2) \\
\hline Constant & + & $\begin{array}{c}0.053 \\
(0.00)^{* * *}\end{array}$ & $\begin{array}{c}0.031 \\
(0.00)^{* * *}\end{array}$ & $\begin{array}{c}0.039 \\
(0.00)^{* * *}\end{array}$ & $\begin{array}{c}0.026 \\
(0.00)^{* * *}\end{array}$ & $\begin{array}{c}0.044 \\
(0.00)^{* * *}\end{array}$ & $\begin{array}{c}0.029 \\
(0.00)^{* * *}\end{array}$ & $\begin{array}{c}0.046 \\
(0.00)^{* * *}\end{array}$ & $\begin{array}{c}0.031 \\
(0.00)^{* * * *}\end{array}$ \\
\hline $\begin{array}{c}\text { Transparency } \\
\text { Index }\end{array}$ & - & $\begin{array}{c}-0.005 \\
(0.01)^{* *}\end{array}$ & $\begin{array}{c}-0.003 \\
(0.03)^{* *}\end{array}$ & $\begin{array}{c}-0.003 \\
(0.00)^{* * *}\end{array}$ & $\begin{array}{c}-0.002 \\
(0.00)^{* * *}\end{array}$ & $\begin{array}{c}-0.004 \\
(0.00)^{* * *}\end{array}$ & $\begin{array}{c}-0.002 \\
(0.00)^{* * * *}\end{array}$ & $\begin{array}{c}-0.004 \\
(0.00)^{* * *}\end{array}$ & $\begin{array}{c}-0.003 \\
(0.00)^{* * *}\end{array}$ \\
\hline $\begin{array}{c}\text { EER } \\
\text { Volatility }\end{array}$ & + & & $\begin{array}{c}0.115 \\
(0.00)^{* * *}\end{array}$ & & $\begin{array}{c}0.119 \\
(0.00)^{* * *}\end{array}$ & & $\begin{array}{c}0.128 \\
(0.00)^{* * *}\end{array}$ & & $\begin{array}{c}0.109 \\
(0.00)^{* * *}\end{array}$ \\
\hline $\begin{array}{l}\mathrm{R}^{2} \\
\text { F Test }\end{array}$ & & $\begin{array}{l}12.3 \% \\
6.44 * *\end{array}$ & $\begin{array}{c}50.4 \% \\
67.08 * * *\end{array}$ & $12.3 \%$ & $51.1 \%$ & $16.4 \%$ & $59.0 \%$ & $20.1 \%$ & $52.4 \%$ \\
\hline $\begin{array}{l}\text { Wald Test } \\
\rho[\operatorname{AR}(1)\end{array}$ & & & & $10.32 * * *$ & $87.16 * * *$ & $27.99 * * *$ & $95.77 * * *$ & $13.68 * * *$ & $48.50 * * *$ \\
\hline $\begin{array}{c}\text { coeff.] } \\
\mathrm{N}=(\mathrm{ixT})\end{array}$ & & 288 & 272 & 288 & 272 & 288 & 272 & $\begin{array}{c}0.496 \\
288\end{array}$ & $\begin{array}{c}0.413 \\
272\end{array}$ \\
\hline$\frac{\text { Specification } t}{\text { F-test (pool }}$ & \multicolumn{8}{|c|}{ Specification tests } & \\
\hline $\begin{array}{r}\text { FEl } \\
\text { Hausman te }\end{array}$ & FEM vs & $2.965 * * *$ & $2.036^{* * *}$ & & & & & & \\
\hline $\mathrm{RE}$ & & 1.982 & 4.452 & & & & & & \\
\hline $\begin{array}{l}\text { Test of cros } \\
\text { independen }\end{array}$ & $\begin{array}{l}\text { ectional } \\
\text { py Frees }\end{array}$ & $2.420 * * *$ & $1.210 * * *$ & $1.521 * * *$ & $0.969 * * *$ & & & & \\
\hline $\begin{array}{l}\text { Test of cros } \\
\text { independence }\end{array}$ & $\begin{array}{l}\text { ectional } \\
\text { y Pesaran }\end{array}$ & $2.979 * * *$ & 0.663 & 0.756 & 0.185 & & & & \\
\hline $\begin{array}{r}\text { Modified W } \\
\text { group } \\
\text { heteroske }\end{array}$ & $\begin{array}{l}\text { test for } \\
\text { se } \\
\text { sicity }\end{array}$ & $1.50 \mathrm{E}+05 * * *$ & $2.60 \mathrm{E}+05^{* * *} *$ & & & & & & \\
\hline
\end{tabular}

Table 3. Panel data estimation results for GDP volatility vs. Transparency.

\begin{tabular}{|c|c|c|c|c|c|c|c|c|c|}
\hline \multirow{2}{*}{$\begin{array}{c}\text { Independent } \\
\text { Variables }\end{array}$} & \multirow{2}{*}{$\begin{array}{c}\text { Expected } \\
\text { Sign }\end{array}$} & \multicolumn{2}{|c|}{ Fixed Effects } & \multicolumn{2}{|c|}{ Random Effects } & \multicolumn{2}{|c|}{ Prais-Winstein } & \multicolumn{2}{|c|}{ Prais-Winstein AR(1) } \\
\hline & & $(1)$ & $(2)$ & $(1)$ & $(2)$ & $(1)$ & (2) & $(1)$ & $(2)$ \\
\hline Constant & + & $\begin{array}{c}0.0182 \\
(0.00)^{* * *}\end{array}$ & $\begin{array}{c}0.0168 \\
(0.00)^{* * *}\end{array}$ & $\begin{array}{c}0.0214 \\
(0.00)^{* * * *}\end{array}$ & $\begin{array}{c}0.0208 \\
(0.00)^{* * *}\end{array}$ & $\begin{array}{c}0.0242 \\
(0.00)^{* * *}\end{array}$ & $\begin{array}{c}0.0241 \\
(0.00)^{* * *}\end{array}$ & $\begin{array}{c}0.0243 \\
(0.00)^{* * *}\end{array}$ & $\begin{array}{c}0.0244 \\
(0.00)^{* * * *}\end{array}$ \\
\hline $\begin{array}{c}\text { Transparency } \\
\text { Index }\end{array}$ & - & $\begin{array}{c}-0.0003 \\
(0.65)\end{array}$ & $\begin{array}{c}-0.0001 \\
(0.85)\end{array}$ & $\begin{array}{l}-0.0008 \\
(0.05)^{*}\end{array}$ & $\begin{array}{l}-0.0007 \\
(0.04)^{* *}\end{array}$ & $\begin{array}{c}-0.0012 \\
(0.00)^{* * *}\end{array}$ & $\begin{array}{c}-0.0012 \\
(0.00)^{* * * *}\end{array}$ & $\begin{array}{c}-0.0012 \\
(0.00)^{* * *}\end{array}$ & $\begin{array}{c}-0.0012 \\
(0.00)^{* * *}\end{array}$ \\
\hline $\begin{array}{c}\text { EER } \\
\text { Volatility }\end{array}$ & + & & $\begin{array}{c}0.0113 \\
(0.21)\end{array}$ & & $\begin{array}{l}0.0115 \\
(0.20)\end{array}$ & & $\begin{array}{c}0.0092 \\
(0.00)^{* * *}\end{array}$ & & $\begin{array}{c}0.0069 \\
(0.02)^{* *}\end{array}$ \\
\hline $\begin{array}{c}\mathrm{R}^{2} \\
\mathrm{~F} \text { Test }\end{array}$ & & $\begin{array}{c}6.9 \% \\
0.21\end{array}$ & $\begin{array}{c}5.6 \% \\
1.00\end{array}$ & $6.9 \%$ & $9.7 \%$ & $8.3 \%$ & $9.1 \%$ & $38.3 \%$ & $37.5 \%$ \\
\hline $\begin{array}{l}\text { Wald Test } \\
\rho[\operatorname{AR}(1)\end{array}$ & & & & $3.73 * *$ & 4.23 & $27.95 * * *$ & $48.26 * * *$ & $17.53 * * *$ & $29.48 * * *$ \\
\hline $\begin{array}{c}\text { coeff.] } \\
\mathrm{N}=\text { (ixT) }\end{array}$ & & 288 & 272 & 288 & 272 & 288 & 272 & $\begin{array}{c}0.2963 \\
288\end{array}$ & $\begin{array}{c}0.2528 \\
272\end{array}$ \\
\hline \multicolumn{10}{|c|}{ Specification tests } \\
\hline $\begin{array}{r}\text { F-test (poole } \\
\text { FEN } \\
\text { Hausman tes }\end{array}$ & $\begin{array}{l}\text { OLS vs. } \\
\text { (FEM vs }\end{array}$ & $4.394 * * *$ & $4.214 * * *$ & & & & & & \\
\hline REN & & 2.357 & 3.964 & & & & & & \\
\hline $\begin{array}{l}\text { Test of cros: } \\
\text { independenc }\end{array}$ & $\begin{array}{l}\text { ectional } \\
\text { by Frees }\end{array}$ & $1.037 * * *$ & $1.312 * * *$ & $1.045^{* * * *}$ & $1.399 * * *$ & & & & \\
\hline $\begin{array}{l}\text { Test of cros } \\
\text { independence }\end{array}$ & $\begin{array}{l}\text { ectional } \\
\text { y Pesaran }\end{array}$ & $8.078 * * *$ & $9.022 * * *$ & $8791 * * *$ & $9.806 * * *$ & & & & \\
\hline $\begin{array}{r}\text { Modified W } \\
\text { group } \\
\text { heteroske }\end{array}$ & $\begin{array}{l}\text { d test for } \\
\text { ise } \\
\text { sticity }\end{array}$ & $39737.52 * * *$ & $16865.45^{* * *}$ & & & & & & \\
\hline
\end{tabular}

By looking the magnitudes of the exchange rate volatility coefficients in the inflation volatility equation compared to the GDP volatility equation, it is obvious that in the former the values are much higher. This result is in line with Keating and Valcarcel, (2012) who argue that the aggregate demand accounts for most of the changes in inflation volatility. Moreover, this higher sensitivity of inflation volatility to exchange rate volatility suggesting smoothness intervention of central banks on exchange rate market as part of their monetary policy strategy. Similarly, when considering the magnitude of the estimated coefficients, the inflation variability seems to be more sensitive to the central bank transparency index compared to GDP 
variability. A result that confirms previous findings in the study of Dincer and Eichngreen (2007).

The F- tests in the specification tests indicate that the fixed effects models outperform the pooled OLS. Moreover, the Hausman test generally indicates that the random-effects model is superior to the fixed-effects model. Therefore, particular attention is given on the randomeffects results presented in columns 5 and 6 of Tables 2 and 3. However, for robustness check FE estimates are also presented. As can be easily seen, there is a significant negative effect of transparency on inflation volatility and on GDP volatility. This effect is not affected by the inclusion of the exchange rate volatility that has a significant positive effect on both volatilities. Additionally, by comparing the two models we can say that the explanation power of transparency on inflation volatility is higher compared to GDP volatility.

The results of the tests suggested by Frees (1995), and by Pesaran (2004) provide evidence for the existence of contemporaneous correlations of errors while the Wald test provides evidence for group wise heteroskedasticity. Therefore, we proceed to the estimation of the models by OLS with PCSEs. In order to take into account for any possible correlation within panels we also estimate models by Prais-Winsten method with PCSEs. Our main results concerning the negative relation between transparency and GDP and inflation volatility are not affected.

\section{Conclusion}

In our model, we empirically investigate the link between central bank transparency and exchange rate variability with inflation and output variability for 36 countries from 1998 to 2005. Our results point out a negative relationship between central bank transparency and inflation and output variability. In effect, monetary policy transparency allows the public to react more quickly to monetary policy actions, discouraging thus the authorities from attempting to manipulate inflation in the pursuit of other objectives. Consequently, in the absence of surprise inflation or unexpected shocks hitting the economy, output is less volatile. An important policy implication of this study could be the identification of which types of central bank disclosure may be responsible for the above results. According to the taxonomy proposed by Geraats (2002) and the measure of transparency employed in this study, there are five aspects of monetary policy transparency, namely, political transparency, economic transparency, policy transparency, operational transparency and procedural transparency. However, the more relevant aspects in actual monetary policy making seem to be political, economic and policy transparency. Firstly, an important step towards more political transparency can be considered the adoption of an inflation targeting strategy in monetary policy. Then, the publication of macroeconomic forecasts helps the public to infer the central bank's intentions from its monetary policy actions and outcomes and thus can be seen as an economic transparency feature. Finally, the disclosure of forward guidance about policy actions (i.e., policy transparency). This allows the private sector to form expectations similar with those of the central bank, enhancing thus the effectiveness of monetary policy.

Additionally, monetary policy should give more attention to exchange rate volatility because it clearly negatively affects its performance in terms of increased inflation and output volatility. Such volatilities, by creating higher uncertainty, affect inflation expectations and therefore the work of monetary authorities becomes more challenging.

\section{References}

Aghion, P., Bacchetta, P., Ranciere, R. and Rogoff, K. (2009) Exchange Rate Volatility and Productivity Growth: The Role of Financial Development, Journal of Monetary Economics, 56, 494-513. 
Arrtibel, O., Furcen, D., Martin, R. and Zdzienicka, A. (2011) The Effect of Nominal Exchange Rate Volatility on Real Macroeconomic Performance in the CEE Countries, Economic Systems, 35, 261-277.

Barone-Adesi, G. and Yeung, B. (1990) Price flexibility and output volatility: the case for flexible exchange rate, Journal of International Money and Finance, 9, 276- 298.

Beetsma, R.M. and Jensen, H. (2003) Why money talks and wealth whispers: Monetary uncertainty and mystique: Comment, Journal of Money, Credit, and Banking, 35(1), 12936.

Bleaney, M. (1999) The Disappearing Openness - Inflation Relationship: A Cross-Country Analysis of Inflation Rates, IMF Working Paper 99-161.

Bleaney, M. and Fielding, D. (2002) Exchange rate regimes, inflation and output volatility in developing countries, Journal of Development Economics, 68, 233-245.

Bleaney, M. and Francisco, M. (2005) Exchange rate regimes and inflation: only hard pegs make a difference, Canadian Journal of Economics, 38(4), 1453-1471.

Carboni, G. and Ellison, M. (2011) Inflation and output volatility under asymmetric incomplete information, Journal of Economic Dynamics and Control, 35(1), 40-51.

Cecchetti, S. G. and Krause, S. (2002) Central bank structure, policy efficiency, and macroeconomic performance: exploring empirical relationships, Federal Reserve Bank of St Louis Review, 84, 47-60.

Dai, M., Sidiropoulos, M. and Spyromitros, E. (2015) Fiscal policy, institutional quality and central bank transparency, The Manchester School, 83(5), 523-545.

Demertzis, M. and Hughes Hallett, A. (2007) Central bank transparency in theory and practice, Journal of Macroeconomics, 29(4), 760-789.

Demertzis, M. and Hughes Hallett, A. (2015) Three different approaches to transparency in monetary policy, Economia Politica, 32(3), 277-300.

Dincer, N. and Eichengreen, B. (2007) Central bank transparency: where, why, and with what effects?, NBER Working Paper 13003.

Duarte, M. and Stockman, A.C. (2002) Comment on: Exchange rate pass-through, exchange rate volatility, and exchange rate disconnect, Journal of Monetary Economics, 49(5), 941946.

Eijffinger, S. C. and Geraats, P. M. (2006) How transparent are central banks?, European Journal of Political Economy, 22(1), 1-21.

de Mendonça, H.F. and Simão Filho, J. (2007) Economic transparency and effectiveness of monetary policy, Journal of Economic Studies, 34(6), 497-514.

Flood, R.P. and Rose, A.K. (1995) Fixing exchange rates-a virtual quest for fundamentals, Journal of Monetary Economics, 36, 3-37.

Frees, E.W. (1995) Assessing cross-sectional correlations in panel data, Journal of Econometrics, 69, 393-414.

Fry, M., Julius, D., Mahadeva, L., Roger, S. and Sterne, G. (2000) Key issues in the choice of monetary policy framework. In Lavan Mahadeva and Gabriel Sterne, eds., Monetary Policy Frameworks in a Global Context, London: Routledge, 3-17.

Geraats, P. M. (2002) Central bank transparency, The Economic Journal, 112(483), F532-F565.

Ghosh, A. R., Gulde, A.-M., Ostry, J. D. and Holger, C. W. (1996) Does the Exchange Rate Regime Matter for Inflation and Growth?, IMF Economic Issues 2.

Ghosh, A. R.; Gulde, A.M., Ostry, J. D. and Holger, C. W. (1997) Does the nominal exchange rate regime matter? NBER Working Paper 5874.

Horváth, R., and Vaško, D. (2016) Central bank transparency and financial stability, Journal of Financial Stability, 22, 45-56.

Hutchison, M., Sengupta, R. and Singh, N. (2012) India's Trilemma: Financial Liberalisation, Exchange Rates and Monetary Policy, The World Economy,35(1), 3-18. 
James, J. G. and Lawler, P. (2015) Heterogeneous private sector information, central bank disclosure, and stabilization policy, Southern Economic Journal, 82(2), 620-634.

Keating, J. and Valcarcel, V. (2012) Greater moderations, Economics Letters, 115(2), 168-171.

Liu, M. H., Margaritis, D. and Tourani-Rad, A. (2008) Monetary policy transparency and passthrough of retail interest rates, Journal of Banking \& Finance, 32(4), 501-511.

Mishkin, F.S. (2004) Can central bank transparency go too far?, NBER Working Paper 10829.

Obstfeld, M. and Rogoff, K. (2000) The six major puzzles in international macroeconomics: is there a common cause?, NBER Working Paper 7777.

Papadamou, S. (2013) Market anticipation of monetary policy actions and interest rate transmission to US Treasury market rates, Economic Modelling, 33, 545-551.

Papadamou, S., Sidiropoulos, M. and Spyromitros, E. (2014) Does central bank transparency affect stock market volatility? Journal of International Financial Markets, Institutions and Money, 31, 362-377.

Papadamou, S., Sidiropoulos, M. and Spyromitros, E. (2015) Central Bank Transparency and the Interest Rate Channel: Evidence from Emerging Economies, Economic Modelling, 48, 167-174.

Papadamou, S., Sidiropoulos, M. and Spyromitros, E. (2016) Interest rate dynamic effect on stock returns and Central Bank Transparency: Evidence from Emerging markets, Research in International Business and Finance, forthcoming, http://dx.doi.org/10.1016/j.ribaf.2016.01.020.

Pesaran, M.H. (2004) General diagnostic tests for cross section dependence in panels, Cambridge Working Papers in Economics 0435.

Schnabl, G. (2009) Exchange Rate Volatility and Growth in Emerging Europe and East Asia, Open Economic Review, 20, 565-587.

Spyromitros, E. (2014) The link between transparency and independence of central banks Journal of Risk \& Control, 1(1), 51-60.

Sutherland, A. (2002) Incomplete pass-through and the welfare effects of exchange rate variability, CEPR Discussion Paper 3431.

Wilhelmsen, B. R. and Zaghini, A. (2011) Monetary policy predictability in the euro area: an international comparison, Applied Economics, 43(20), 2533-2544. 